\title{
成人巨大尿管症の検討
}

\author{
佐賀医科大学外科学泌尿器科教室（主任：真崎善二郎教授） \\ 吉永 英俊 平田 祐司 藤山 千里 \\ 市木 康久 井口 厚司 真崎善二郎 \\ 南里医院（院長 南里和成） \\ 南里和成
}

\section{MEGAURETER IN ADULTS}

Hidetoshi Yoshinaga, Yuji Hirata, Chisato Fujiyama, Yasuhisa Ichigi,

Atsushi Iguchi and Zenjiro Masaki

Division of Urology, Department of Surgery, Saga Medical School

(Director: Prof. Z. Masaki)

Kazushige Nanri

Nanri Clinic

(Chief: K. Nanri)

In comparison with megaureters in children, their reports in adult are not common. We had an opportunity to treat seven adults with megaureters during the last six years. They were all female and ages ranged from 46 to 67 years. Five patients with grade II and one with grade III (Pfister-Hendren's classification) were treated by reconstructive surgery, excision of the narrow segment, taparing of the dilated lower ureter and reimplantation through a submucosal tunnel. The outcome of all the grade II patients was excellent and the case with grade III showed mild improvement. The results suggested that surgical reconstruction could be equally effective for megaureters in adults compared to those in children.

Key words: adult, megaureter, reconstruction

要旨：過去 6 年間に 7 例の成人巨大尿管症を経験した。年齢は 46 67歳（平均53.7歳）で，すべて女性 であった．偶然発見例が 4 例あり，残り 3 例はそれぞれ腎盂炎，血尿，嘔気嘔吐で受診した．全例が片 側性で, 左 5 例, 右 2 例であった. Pfister-Hendren の重症度分類で grade I 1 例, grade II 5 例, grade III 1 例で, grade II 以上の 6 例に再建術（Tapering and Reimplantation）を行った。尿漏などの合併 症もなく, 術後平均15日目に尿管ステントは抜去した。術後平均観察期間は 25.4 力月で grade II の 5 例 は著明に改善し, grade III 1 例は軽度の改善に留まった. 成人の場合積極的治療の要否には議論のある ところであるが，上記成績は再建術の有効性を示すものと考えられた。

キーワード：成人, 巨大尿管症, 再建術

\section{緒言}

巨大尿管症は尿路奇形の中では稀なものではない が，小児に較べて成人での報告は少なく，成人例に対 する治療方針や手術法について述べたものはほとんど みられない.われわれは過去 6 年間に 7 例の成人巨大 尿管症を診断し，6例に尿路再建術を行い良好な結果 を得たので報告する。

\section{対象と方法}

1986年から1992年までの 6 年間に成人原発性巨大尿 管症の 7 例 ( 7 㽷管) を経験した。年齢は $46 〜 67$ 歳 (平 均53.7歳）で，すべて女性であった。患側は左 5 例， 右 2 例で，対側は正常であった，過去に㽷路感染症の 既往があったのは 3 例で，結石を合併しているものは 1 例（症例 3 ）であった. 4 例は検診や他疾患の検査 時に偶然発見されたものであり，腎盂炎・血尿・嘔気 
Table 1 Summary of 7 patients with primary obstructive megaureter

\begin{tabular}{|c|c|c|c|c|c|c|c|c|}
\hline Case & Age & Sex & $\begin{array}{l}\text { Affected } \\
\text { side }\end{array}$ & $\begin{array}{c}\text { Previous } \\
\text { UTI }\end{array}$ & Presentation & Grade $^{2)}$ & Treatment & $\begin{array}{c}\text { Outcome } \\
\text { (follow up) }\end{array}$ \\
\hline 1 & 56 & $\mathrm{~F}$ & $\mathrm{~L}$ & + & incidental & II & $\mathrm{T}+\mathrm{R}^{*}$ & $\begin{array}{l}\text { excellent } \\
(15 \mathrm{~m})\end{array}$ \\
\hline 2 & 46 & $\mathrm{~F}$ & $\mathrm{~L}$ & + & pyelonephritis & II & $T+R$ & $\begin{array}{l}\text { excellent } \\
(72 \mathrm{~m})\end{array}$ \\
\hline 3 & 67 & $\mathrm{~F}$ & $\mathrm{R}$ & + & hematuria & II & $\mathrm{T}+\mathrm{R}$ & $\begin{array}{l}\text { excellent } \\
(13 \mathrm{~m})\end{array}$ \\
\hline 4 & 47 & $\mathrm{~F}$ & L & - & $\begin{array}{l}\text { nausea, } \\
\text { vomitting }\end{array}$ & II & $T+R$ & $\begin{array}{l}\text { excellent } \\
(30 \mathrm{~m})\end{array}$ \\
\hline 5 & 63 & $\mathrm{~F}$ & L & - & incidental & II & $T+R$ & $\begin{array}{l}\text { excellent } \\
(10 \mathrm{~m})\end{array}$ \\
\hline 6 & 48 & F & L & - & incidental & III & $\mathrm{T}+\mathrm{R}$ & $\underset{(19 \mathrm{~m})}{\operatorname{mild}}$ \\
\hline 7 & 51 & F & $\mathrm{R}$ & - & incidental & I & Conservative & $\begin{array}{l}\text { no change } \\
(19 \mathrm{~m})\end{array}$ \\
\hline
\end{tabular}

Fig. 1 Severity of primary megaureter. grade I : normal pyelocalyceal system and distal ureteral dilatation. grade II : some pyelocalyectasis and ureterectasis. grade III : hydronephrotic atrophy ${ }^{2}$.

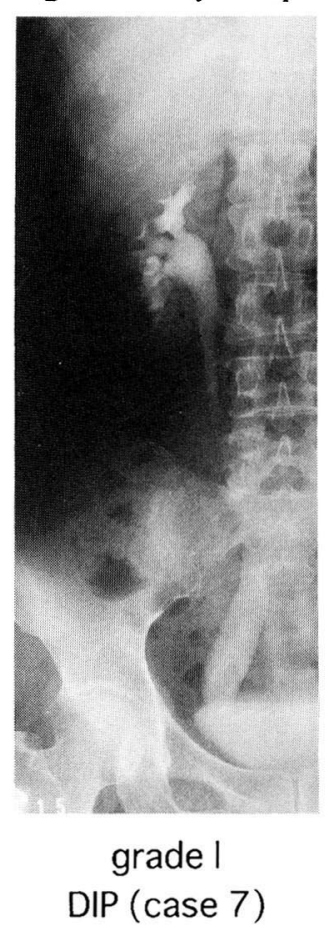

DIP (case 7)

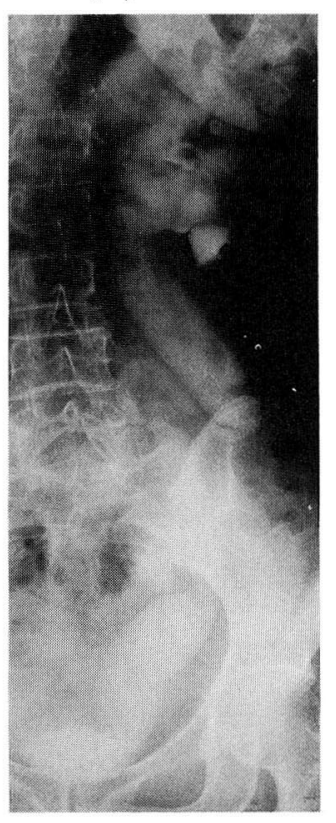

grade II

DIP (case 5)

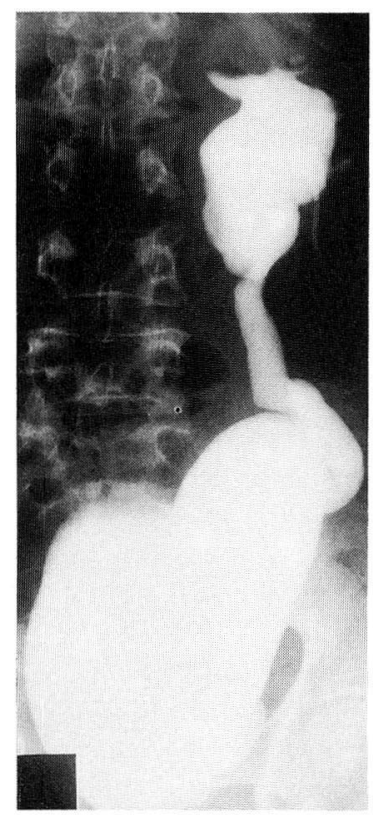

grade III

RP (case 6)
嘔吐の症状を有していたものが 1 例ずっであった (Table 1).

超音波検查・IVP（または DIP）・膀胱鏡検査・逆行 性腎孟造影 (以下 RP と略) - 排尿時膀胱造影を全例に 行った。いずれの症例に扔いても膀胱尿管逆流は認め
ず，尿管カテーテルの挿入も可能であった。レノグラ ムは 5 例に行い, 全例 obstructive pattern を示した. 国際小児泌尿器科学会の巨大尿管症の分類 ${ }^{11} て ゙$ 全例非 逆流性非閉塞性巨大尿管症, 原発性に相当した。重症 度分類は Pfister-Hendren の基準 ${ }^{2)}$ に従うと grade I 
Fig. 2 Left: Preoperative DIP shows grade II in 47 year-old woman (case 4). Right: DIP 8 months after tapering and reimplantation of the ureter.
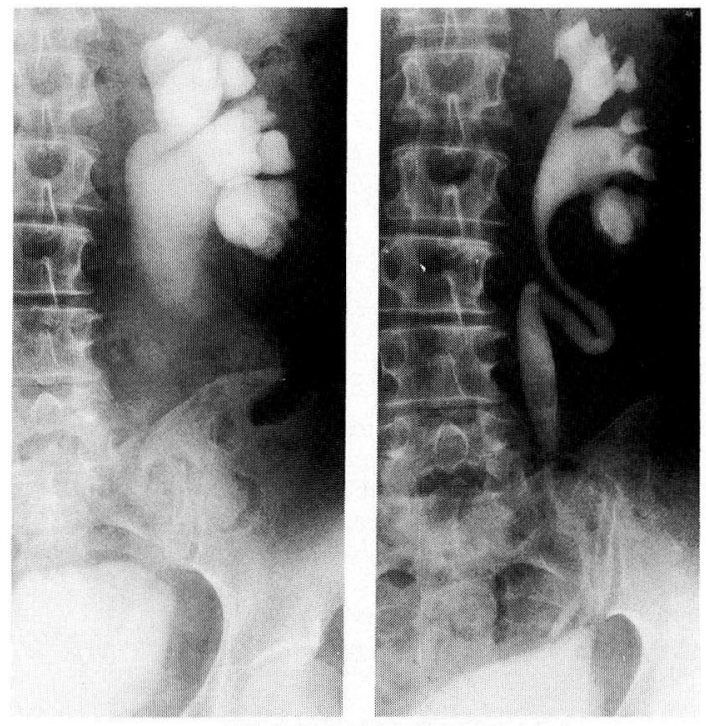

1 例, grade II 5 例, grade III 1 例であった（Table 1, Fig. 1).

grade Iの 1 例は経過観察とし, grade II 以上の 6 例 に Hendren らの方法 ${ }^{2)}$ に従って尿路再建術を行った. すなわち，下部尿管を血行保存に留意しながら剥離し narrow segment を切除した. 拡張部尿管を平均長 $8.25 \mathrm{~cm}(7 〜 10 \mathrm{~cm})$ にわたって裁断し， $12 \mathrm{Fr}$ splint catheter を締め付けない程度に tapering した. 尿管膀 胱の吻合は粘膜下トンネル法で行った。

\section{結 果}

術後は全例尿漏れなどの合併症もなく，尿管 stent は平均15日目に抜去した。術後の平均観察期間は 25.4 カ月（10〜72力月）で 6 〜2力月毎にIVP（または DIP)を行った. grade II の 5 例はいずれも著明な水腎 症の改善が得られた (Fig. 2). grade III の 1 例は軽度 の腎機能の改善であった.

narrow segment についての病理組織学的検討が可 能であった 3 例（症例 $1 ， 4 ， 5$ ）で，縦走筋の中に 一部輪状走行の筋束がみられた。さらに症例 1 では筋 線維間のコラーダンの増加があり, 症例 4 では尿管壁 の筋層が一部欠損していた．拡張部尿管はほとんどの 症例でコラーゲンの増加と軽度の細胞浸潤がみられ た.

\section{考 察}

巨大尿管症は1923年 Caulk が第 1 例を報告後 ${ }^{3)}$ ，今 日まで新生児・小児例は多数報告されている(4) 7)。一 方, 成人の巨大尿管症は小児に較べると稀で, 成人例 についてまとめた報告はわずか数編に過ぎな (28) 11). 小児では男子の罹患頻度が女子の $3 \sim 5$ 倍と され，また左に多いとされている，それに対して成人 では女の割合が増え, Hanna らは男16人・女10人 ${ }^{81}$, Heal ら は男 6 人・女 9 人 $^{9)}$, 中村らは男 3 人・女 4 人 ${ }^{101}$ と報告しており，自験例は全例女性であった。

巨大尿管症の発生要因についてはまだ議論の多いと ころであるが, 最近の報告では, narrow segment の, (1)尿管筋層, 特に蠕動に関する縦走筋の dysplasia や 配列異常 ${ }^{12113)}$, (2)尿管のコラーゲン組織の増加 ${ }^{14)}$, (3)拡 張部尿管の異常 ${ }^{15)}$ な゙がいわれている，われわれの症 例も検討できた 3 例とも narrow segment の縦走筋の なかに一部輪状走行の筋束がみられ，1例でコラーゲ ンの增加，もう1例で尿管壁の一部に縦走筋の欠損を 認めた。したがって成人に見られる巨大尿管症もその 多くは小児と同様な原因で発生したものと思われる.

治療に関して, Keating らは classical な小児の巨大 尿管症の場合と異なり新生児の primary, obstructive megaureter では約半数に自然軽快がみられており, 悪化したり変化のみられないものは中等度・高度の症 例であったとしている. 従って, 成人で発見される巨 大尿管症は, 新生児期は中等度以上であった可能性が 高い.

成人に巨大尿管症を発見した場合治療に当たって最 も迷う点は, これらの症例の尿路通過障害が長年を経 て次第に進行してきたものであるのか, あるいは診断 時に見られる変化はすでに幼小児時に起こったもので あり現在はすでに stable な状態であるのかという判 断である. 前者であれば治療したほうが良いであろう し, 後者であれば治療の必要はないと考えられる。こ のことを明らかにするためには長期経過観察するほか 道はないが, 注目すべき点は grade II の症例において 全例手術後水腎症が著明に改善したことである，同じ ような成績は中村らによっても報告されており，成人 巨大尿管症 7 例中手術を行った 6 例で水腎症の改善が 得られている10).このことは術前にはある程度バラン スのとれた,あるいはそれに近い状態であったにせよ， ある程度尿路の通過障害という負荷がかかっており, 多少なりとも進行していたという見方ができるものと 考えられる。もちろん成人巨大尿管症すべてが進行性 
とみなすのは極端すぎる考えと思われる，事実 Heal らは成人の巨大尿管症の半数以上を conservative $に$ みており，なかには 16 年あるいは 40 年にわたって経過 観察している症例もある ${ }^{9}$. われわれは grade I の症例 については conservative にみているが,これは上記理 由からである。

手術法としては narrow segment を切除し, 粘膜下 トンネル法で膀胱に吻合することになるが，拡張した 下部尿管の処置としては, (1) tapering 法"2)と, (2) folding 法 $^{16)}$ がある. folding 法は小児では可能と思われる が，成人例では尿管のサイズが大きいだけでなく尿管 壁の肥厚したものが多く，粘膜下トンネル法は行い難 いと思われる。われわれは全例 tapering 法で行い良好 な結果を得ることができた。

自験例は 7 例中 4 例が偶然発見されたものであり， 画像診断技術の進歩，検診率の向上により偶然発見さ れる機会は増えてくるものと予想される．その治療に 際しては中等度以上の症例では再建術により満足のい く結果が得られた。年齢・全身状態・症状の有無を考 慮したうえで, 重症度に応じた治療法の選択が重要と 考えられた。

\section{文 献}

1) Smith, E.D., et al. : Report of working party to establish an international nomenclature for the large ureter. in Bergsma, D. and Duckett, J.W. (eds.), Birth Defects. Original Articles Series, Vol. 13, No. 5, 1977, pp. 3-8.

2) Pfister, R.C. and Hendren, W.H.: Primary megaureter in children and adults. Clinical and pathophysiologic features of 150 ureters. Urology, 12, 160-176, 1978.

3) Caulk, J.R.: Megaloureter: The importance of the ureterovesical valve. J. Urol., 9, 315$330,1923$.
4) Keating, M.A.: Changing concepts in management of primary obstructive megaureter. J. Urol., 142, 636-640, 1989.

5) Hanna, M.K. and Jeffs, R.D. : Primary obstructive megaureter in children. Urology, 6, 419427, 1975.

6) Retik, A.B., McEvoy, J.P. and Bauer, S.B.: Megaureter in children. Urology, 11, 231-236, 1978.

7) Hendren, W.H.: Complication of megaureter repair in children. J. Urol., 113, 238-254, 1975.

8) Hanna, M.K. and Wyatt, J.K.: Primary obstructive megaureter in adults. J. Urol., 113, 328-334, 1975.

9) Heal, M.R.: Primary obstructive megaureter in adults. Br. J. Urol., 45, 490-496, 1973.

10) 中村正広, 櫻井 勗, 多田安温, 辻本幸夫, 藤岡秀 樹, 柏井浩三 : 成人巨大尿管症の 7 症例. 泌尿紀 要, 29, 931-936, 1983.

11）岡野 学, 米田尚生, 秋野裕信, 磯松幸成, 村中幸 二, 蟹本雄右, 清水保夫, 河田幸道 : 巨大尿管症の 1 例. 泌尿紀要, 32, 764-768, 1986.

12) Tokunaga, S., Gotoh, T., Koyanagi, T. and Miyabe, N.: Muscle dysplasia in megaureters. J. Urol., 131, 383-390, 1984.

13）徳永荘平: 巨大尿管症の研究一病理と水力学. 日 泌尿会誌，71，1293-1312，1980.

14) Gregoir, W. and Debled, G.: L'etiologie du reflux congenital et du megaureter primarie. Urol. Int., 24, 119-134, 1969.

15) McLaughlin, A.P. III, Pfister, R.C., Leadbetter, W.F., Salzstein, S.L. and Kessler, W.O.: The pathophysiology of primary megaloureter. J. Urol., 109, 805-811, 1973.

16) Ehrlich, R.M. : The ureteral folding technique for megaureter surgery. J. Urol., 134, 668-670, 1985.

（1994年 3 月 18 日受付，10月 3 日受理） 